\title{
Shedding Light on 17th century Trade and Diplomacy: pXRF Analysis of VOC Cannons in Vietnam
}

\section{Claire Holubowskyj}

University of Oxford

\begin{abstract}
Three unique bronze 17th century Dutch East India Company (VOC) cannons stored in the Hu êRoyal Antiquities Museum were analysed using portable X-Ray Fluorescence (pXRF). The VOC was an early pioneer of long-distance cross-continental trade, and used cannons as tools to negotiate diplomatic relationships.

These cannons represent a range of provenances: VOC-made for their own use, VOC-made gifts, and Vietnamese commissions. Both sides benefitted from their exchange: the VOC from trade access, and the Vietnamese from military and status associations. Considering them using scientific and visual methods therefore highlights the complex nature of cross-cultural contact and diplomacy.
\end{abstract}

\section{Key words}

pXRF, VOC, Cannon, Vietnam, Bronze, 17th century

\section{Introduction}

Three unique bronze cannons from the 17th century are stored in the Hu êRoyal Antiquities Museum in central Vietnam. Produced by the Vereenigde Oostindische Compagnie (the Dutch East India Company, or VOC), they can be studied as proxies for early colonial diplomacy and trade.

My research questions are centred on the use of scientific methods to augment traditional analyses and assess the significance and impact of these cannons. Situating this analysis within wider historical contexts illustrates 
how these cannons reflect the power dynamics and shifting agency between the VOC and Vietnamese powers during specific historical periods.

This was achieved through investigation of the cannons in the Hu êRoyal Antiquities Museum with portable XRay Fluorescence (pXRF), which was able to non-destructively analyse their composition to contribute data on the trace elements present (Williams and Carter, 2009: 30). This data is considered in conjunction with visual analysis and archival data to situate the cannons within their broader social contexts and the developing relationship between Vietnamese powers and the VOC.

\section{Background}

The 17th century, a period of global trade and exploration, saw a number of European powers establish colonial relations in Southeast Asia in the pursuit of valuable trade goods such as spices, porcelains, and silk. Following the establishment of a base in Batavia (modern Jakarta) in 1619, VOC trade flourished due to its unique policies of financing trade to Europe with intra-Asian trade networks.

VOC trade emphasised the acquisition of spices, which the VOC purchased from the Banda Islands with silver, gold, and textiles such as silk. These goods were exchanged for copper and Chinese ceramics in Japan, perishable materials from the coast of Mainland Southeast Asia, and miscellaneous goods as part of an extensive intra-Asian trade network. Sources, purchase prices, and locations were not only in line with market shifts, but also dependent on long-standing diplomatic relationships.

Due to Ming dynasty policies of trade prohibition, foreign traders were forbidden to enter China (Boxer, 1979: 59). The Dutch needed continued access to Chinese silks and ceramics, and responded to the Ming policies by fostering a trade relationship with Japan. A consequence of this was that VOC ships increasingly sailed via Siam and Vietnam (Parthesius, 2010: 58).

Vietnam originated as a southern extension to regional Chinese power, before developing into an independent local state controlled by the Trịnh lords in the north, and the rival Nguyễn lords in the south (Lien and Sharrock, 2014: 130). The VOC built a relationship with the Trịnh on the grounds of mutual necessity. The VOC needed Tonkin silk to finance intra-Asian trade, and the Trịnh lords needed armaments to use against the Nguyễn. As such, both the VOC and the Vietnamese seized the initiative in their trade relationship at different times, using cannons as means of achieving ulterior motives. To that end, this analysis has the potential to shed light on diplomatic nuance otherwise invisible to the naked eye.

\section{Methodology}

The compositions of three unique VOC cannons were non-destructively analysed using pXRF (Bruker, 2006: 4). My research aims were to identify trace elements, corroborate documentary evidence, and identify any incongruities. The pXRF machine used in my study is a 2006 Tracer III-V, manufactured by Bruker.

Due to inherent inaccuracies in use, readings were interpreted qualitatively as markers for the presence of elements and their broad quantities. Similar areas were prepared and tested in the same way to ensure 
consistency and minimise the introduction of errors. Data analysis was conducted using dedicated Bruker-made S1PXRF software.

\section{Results}

The first cannon was forged in 1661 for a VOC fluyt by Gerard Koster Jr. in Amsterdam. This cannon was most likely sold to the Trịnh lords in 1674 as part of a larger shipment of cannons and cannonballs (Truong, 2011: 133). pXRF results from this cannon corroborated expectations for the composition of VOC cannons.

The second cannon was forged by Dutch gunfounder Kylianus Wegewaert in 1640, and was commissioned by the VOC as a gift to the Trịnh lord (Truong, 2011:136). pXRF analysis revealed it is of comparable manufacture to the first cannon, though its unusual Asian-inspired decorations have implications for its role as a diplomatic tool.

The third cannon, cannon 54, is of unknown origin, but was supposedly commissioned from the VOC in 1677 by the Trịnh lord (Truong, 2011: 137). The casting technique and bronze quality of this cannon are both visibly poorer than that of the other cannons. Featuring hybrid decoration, the unusual imagery used, and the more inconsistent pXRF results collected make it unlikely that it was founded by a known gunfounder in the Netherlands.

The Koster and Wegewaert cannons were both commissioned by the Dutch to achieve Dutch goals, and so the consistent standards seen are as expected. While both the Wegewaert cannon and cannon 54 were Dutch-made gifts to the Trịnh lords, their contexts are very different. The initiative behind the Wegewaert cannon was Dutch, whereas cannon 54 was supposedly commissioned by the Vietnamese, and therefore has different diplomatic significance. The poorer production quality reflects this: whether the different production standards were deliberate or coincidental, they reflect the relative importance of each gift to the VOC administrators and diplomats organising the processes of gifting and managing relations with the Vietnamese rulers.

\section{Significance}

The earliest of the three $17_{\text {th }}$ century cannons studied, the Wegewaert cannon, was produced as tribute, with an accordingly short period of elapsed time between commission and delivery. Forged in 1640, it was given to the Trịnh lord in 1642. The maximum time lapse of two years reveals the cannon was exported from the Netherlands at the earliest possible opportunity.

These dates are significant, as this took place immediately after initial diplomatic contact was established following the failure of VOC diplomacy with the Nguyễn. This highlights the VOC's urgency to confirm good relations, while the unique motifs used represent efforts to tailor the cannon to Southeast Asian aesthetics.

The Koster cannon was produced in 1661 for a VOC fluyt, and was likely sold to the Vietnamese in 1674 (Truong, 2011: 133). The date of gifting was not coincidental, as it followed two requests for cannons made in 1667 and 1670, and the end of the third Anglo-Dutch War. The establishment of peace between the Trịnh and

Nguyễn created a degree of political stability the VOC needed to capitalise on to ensure continued access to 
silk. As the Koster cannon was present in the region and newly superfluous due to the end of active warfare, the act of gifting it represents the appropriation of existing resources to fulfil diplomatic agendas.

Less is known about cannon 54 due to the lack of maker's marks and the corresponding uncertainty of supporting evidence. The poorer production quality is unusual, and distinguishes it from known VOC cannons. It is likely that inferior skill or technology was employed in its production, and highlights a lack of concern for the reception of this cannon, as it was gifted at a time when the diplomatic importance of Vietnam was waning.

\section{Conclusion}

By comparing known documentary evidence to pXRF results, my research was able to highlight the stylistic and material distinctions between the cannons analysed. The differences between them emphasise the importance the VOC placed on maintaining Vietnamese relations at the time the cannons were gifted. This correlation between cannon quality and importance of relationship has significant impacts on the interpretation of data from cannon 54, which will be analysed in greater detail as part of ongoing research.

\section{Acknowledgements}

Thanks to Huynh Thi Anh Van and the team at the Hu ếRoyal Antiquities Museum for granting access to the cannons there and being accommodating with their time and efforts. This research would not have been possible without the patience and assistance of Damian Robinson, Chris Doherty, and Trần Quang Anh, who have gone out of their way to provide invaluable assistance. Immense gratitude also goes to my family and friends for the endless support I am always grateful for.

\section{Reference List}

Boxer, C. R., 1979, Jan Compagnie in War and Peace 1602-1799. Heinemann Asia, Hong Kong.

Bruker, 2006, Tracer III-V User's Manual.

Lien, V. H. and Sharrock, P., 2014, Descending Dragon, Rising Tiger: a History of Vietnam. London: Reaktion Books.

Parthesius, R., 2010, Dutch Ships in Tropical Waters: The Development of the Dutch East India Company (VOC) Shipping Network in Asia 1595-1660. Amsterdam: University Press.

Truong, P., 2011. V ềBa Khẩu Súng Thần Công Hà Lan ỞBảo Tàng C ổVật Cung Đình Huế. Tạp chí Nghién cúu và Phát triển 6, 128-138.

Williams, D. B. and Carter, C. B., 2009 (second edition), Transmission Electron Microscopy: A Textbook for Materials Science. New York: Springer. 